\title{
Editorial
}

\section{Pós-Graduação e Conselho Federais e Regionais de classes}

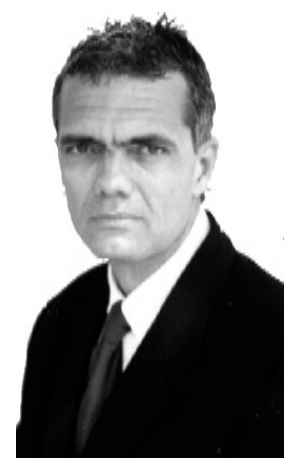

Marco Antonio Guimarães da Silva,Med.Dr.Sci. marco@atlanticaedu.com.br

Quando o identificador de chamada do meu celular, que lamentavelmente sempre me acompanha, mostrava o número do meu editor executivo preferido, já sabia que vinha cobrança para o editorial que a cada dois meses escrevo para a revista Fisioterapia Brasil. Não consegui tornar-me importante o suficiente para prescindir de maldito aparelho portátil. A partir de então, tive que convencer-me de que parte do meu final de semana, que já se anunciava com uma fria e chuvosa tarde de sexta, seria dedicado à produção do citado editorial e a dura tarefa de ter que comparecer a zona eleitoral para anular o voto.

O editor executivo, sabedor do meu estilo literário pouco ortodoxo, sugeriu que eu tomasse um avião e buscasse inspiração através de um olhar perdido para a vasta imensidão das nuvens e céus, invocando o sem número de escritores e filósofos que há tantas ediçôes vêm ao meu socorro.

Resolvi desconsiderar a sugestão e o bendito amparo outrora conseguido, focalizando a atençáo para um tema que tem suscitado polêmica na esfera de alguns conselhos profissionais de classe, que é o da obrigatoriedade de término da graduação para ingresso na pós-graduação, especificamente nos cursos de lato sensu.

Algum desses órgãos, fugindo de sua área de competência legal, tem emitido juízo de julgamento improcedente, afirmando que não reconhecerão os títulos emitidos por universidades que tenham ferido o artigo artigo 44, inciso III, da LDB.

A titulação acadêmica está sob a responsabilidade do Ministério de Educação e, pelo que se sabe, além de não pertencerem a essa autarquia, os conselhos não possuem competência jurídica e cognitiva para julgar se um título dado por uma universidade tem ou não validade.

Fundamentalmente, o acesso à pós-graduação exige a conclusão da graduação (artigo 44, inciso III, da LDB). "Mas, as instituiçóes de ensino possuem a prerrogativa de fixar exigências complementares e decidir sobre a compatibilidade da área de formação com o aprofundamento de estudos desejado" (site da CAPES). Dentro dessa prerrogativa ou de outras que desconheço, é que algumas instituições de ensino superior talvez se amparem para permitir que alunos que sequer terminaram os cursos de graduação defendam suas teses de mestrado ou doutorado.

Cito duas situações, vividas por pessoas bastante próximas, que póem abaixo os argumentos desses senhores ou senhoras, burocratas por idealismo e pretensamente especialistas em assuntos educacionais: a primeira refere-se a uma aluna do curso de graduação de universidade pública federal, que, enquanto estava no quarto período da graduaçáo, já iniciava o mestrado em universidade pública federal; a segunda refere-se a um aluno que, ainda no último ano do segundo grau, já iniciava a dissertaçấo de mestrado em órgão de excelência na área , nota máxima da CAPES (com bolsa de órgão governamental). Ambos os alunos realizam, atualmente, uma trajetória acadêmica em ascensão. O primeiro caso cursa o doutorado na prestigiada Universidade de Paris VII, França, e o segundo, após uma tese de doutoramento brilhante em Cambridge - Inglaterra, segue um pós-doutorado na França. Ressalte-se que este último, já no pós-doutorado, sequer terminou a graduação. É obvio que os dois alunos em questão tiveram que passar por criterioso processo de seleção, seja para a obtenção da bolsa de estudos seja para admissáo aos seus respectivos cursos de mestrado, doutorado e pós-doutorado.

Há que se notar, ainda, que os exemplos dados se referem à pós- graduação stricto sensu, que, como sabemos, se encontra alguns degraus acima do lato sensu, atual pomo da discórdia, em termos de acesso e exigências.

Tais equívocos em relação ao aperfeiçoamento acadêmico talvez pudessem ser evitados se substituíssemos as eleiçôes para dirigentes desses órgãos de classe por concurso. O processo de seleção iria considerar níveis cognitivos centrados principalmente na legislação e jurisprudência do trabalho, da educação e da ciência, em questôes éticas e em temas sociológicos. O conselho de classe, como formação social, é uma estrutura em dominância, que exibe certo tipo de configuração e de 
estruturação definida e complexa e que, portanto, não pode estar à mercê de reducionismos. Mais do que de um órgão que policie as atividades profissionais, necessitamos de dirigentes que rompam com as concepçóes monísticas e com velhos protocolos e que aprendam a viver nas diferenças e com elas, tornando-se capazes de pensar sobre as articulações nas diversas contradiçóes.

É lastimável que, em algumas situações, os profissionais dirigentes ainda concebam o conselho como a vontade unificada do comitê de classe dominante. O conselho tem que ser a instância de atuação de uma condensação que transforme as práticas distintas em uma pratica sistemática de regulação, de norma e de normalização dentro da sociedade.

Para escrever o presente texto, náo recorri, como em editoriais passados, ao pensamento de literatos, sociólogos e filósofos. Mas gostaria de, ao terminá-lo, sugerir aos senhores dirigentes de órgáos de classe que, antes de dar informaçóes equivocadas aos seus associados, procurassem ler algo sobre a re-conceituação ideológica de Althusser, a desconstrução de Derrida, a teorização da formação social de Marx ou as idéias contra o reducionismo economicista e funcionalista de Engels. Fosse, entretanto, essa sugestão factível, provavelmente esse editorial teria tomado outro rumo. 